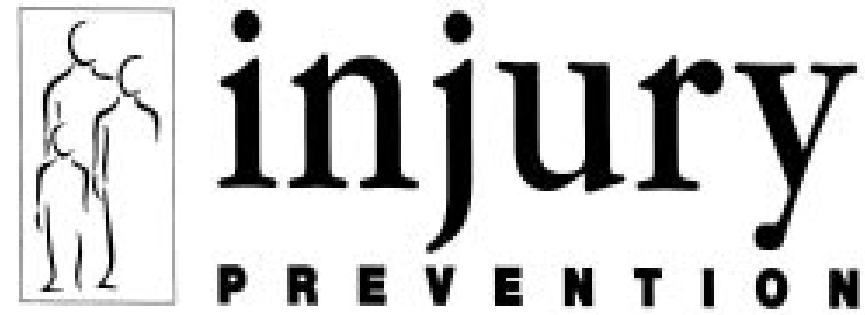

Journal of the International Society for Child and Adolescent Injury Prevention

\title{
Editorial
}

\section{Desk cleaning}

With this, the first issue of volume 4 , it seemed a good time to clean my desk. One of the mixed blessings of being an editor is the mail you receive, even though it is not all laudatory. My mail includes reports, journals, and newsletters, and in the past I used some of these to write the News and Notes section. Now that this responsibility lies with Mike Hayes, these reports serve to keep me familiar with what is happening in the field, in the trenches, on the front lines (choose your metaphor...pity they are all military!) Before these reports move from desk to drawers, I always read them, and want now to share some thoughts arising from them.

The growth of injury prevention programs internationally is gratifying, but can also be confusing. It is no longer easy to know who else is "out there". But we need to know what others are doing so we can learn from them. To help us move in this direction, based on what was on my desk, supplemented by a question I placed on ISCAIPNET, I decided to provide a table listing the major players (see table 1). There is a danger in doing this because inevitably some will be overlooked. I urge organizations that have been neglected to let me know and I will do my best to rectify this.

I had intended to include in this table not only groups that are typically voluntary and community based, but governmental bodies as well. To avoid being swamped with local, state, or provincial organizations of either kind, however, I decided to stick to national, non-governmental organizations and programmes that specifically focus on children or adolescents. The scientist in me prompted me to cross tabulate certain key elements for each group, although I hesitated for fear that some might interpret the information in terms of judgments about which pro- gramme was better. This was not my intention and even if it were, the many gaps in the table make this impossible.

This exercise was conducted in the spirit of maintaining the delicate balance in this journal between research and practice. As will be evident to regular readers, the balance remains tilted towards the scientific side. We have come to realize - and reluctantly accept - that it is difficult for programme managers to write about their work. Certainly it is more difficult than it is for researchers, perhaps because the former have less reason to do so. Clearly, they have fewer incentives in comparison to those that exist for academics. There may actually be disincentives in the sense that time spent writing for a journal, is time away from fund raising and programme execution.

Nevertheless, annual reports do get written, as do newsletters, and all find their way to my desk. The sheer number of such reports suggests that we have reached, or soon will reach, a critical mass internationally. But in a general sense it seems there are now enough groups working towards child and adolescent injury prevention to prompt serious discussion of both advocacy and research at the international level. It is hard to imagine why any groups might not be members of ISCAIP - clearly, the logical mechanism for achieving any coordinated, international child injury promotion initiative. Although to date it has been difficult for the Society to play this role, I assume much of this will change after the Fourth World Conference in Amsterdam.

In part, the Society's difficulties so far may be simply a function of its youthfulness. Whatever the reasons, this editorial is a call to arms. It challenges any group, at whatever level, government or community, that is not a member of ISCAIP to answer "why not?" I cannot imagine any

Table 1 Major non-governmental national child injury prevention organizations or programmes

\begin{tabular}{|c|c|c|c|c|}
\hline Country & Organization & Contact person & Year begun & Staff \\
\hline Australia & Kidsafe Australia & I Scott & 1979 & 30 (most part time) \\
\hline Austria & Austrian Committee for Injury Prevention in Childhood & K Purtscher & & \\
\hline Canada & Safe Kids Canada & S Corkum & 1992 & 6 \\
\hline France & Centre d'Information et de Rencontre pour la Prevention des Accidents d'Enfants & B Leveque & & \\
\hline New Zealand & Safekids NZ & R Kokotaillo & 1992 & 4 \\
\hline Portugal & Association for the Prevention of Child Safety & M Cordeiro & & \\
\hline South Africa & Child Accident Prevention Foundation Southern Africa & D Bass & & \\
\hline Sweden & Swedish National Injury and Safety Promotion Program & L Schelp & 1992 & 11 \\
\hline \multirow[t]{2}{*}{ US } & National Safe Kids Campaign & H Paul & & \\
\hline & Children's Safety Network & S Gallagher & & \\
\hline UK & Child Accident Prevention Trust & C Sherriff & 1981 & 10 \\
\hline
\end{tabular}


Table 2 Legislative responsibilities for injury prevention in Canada

\begin{tabular}{|c|c|c|}
\hline Injury type & $\begin{array}{l}\text { Level of } \\
\text { responsibility }\end{array}$ & Department \\
\hline Household products & Federal & Health Canada \\
\hline \multirow[t]{2}{*}{ Motor vehicle } & Federal & Transport Canada \\
\hline & Provincial & Ministries of Transport \\
\hline \multirow[t]{2}{*}{ Road safety } & Provincial & Ministry of Transport \\
\hline & Municipal & Law enforcement \\
\hline Bicycling & Provincial & Ministry of Transport \\
\hline Pool drowning & Provinicial & $\begin{array}{l}\text { Ministry of Labour } \\
\text { Department of Planning and } \\
\text { Development }\end{array}$ \\
\hline Boating & Federal & $\begin{array}{l}\text { Department of Fisheries } \\
\text { Transport Canada } \\
\text { Justice Canada }\end{array}$ \\
\hline Housing & Provincial & $\begin{array}{l}\text { Ministries of Labour } \\
\text { Department of Planning and } \\
\text { Development }\end{array}$ \\
\hline Burns and poisoning & Federal & $\begin{array}{l}\text { Agriculture and Agrifood } \\
\text { Health Canada } \\
\text { Industry Canada }\end{array}$ \\
\hline $\begin{array}{l}\text { Pharmaceutical } \\
\text { packaging }\end{array}$ & $\begin{array}{l}\text { Federal } \\
\text { Provincial }\end{array}$ & $\begin{array}{l}\text { Health Canada } \\
\text { Ministry of Health }\end{array}$ \\
\hline Playgrounds & Municipal & $\begin{array}{l}\text { Departments of Planning and } \\
\text { Development }\end{array}$ \\
\hline
\end{tabular}

reply that makes sense other than the possibility that the Society's mission is not yet clear, or the cost of joining is too high. I cannot speak to the latter, but I do insist that if it is not yet clear it soon will be that ISCAIP's mission includes international collaboration and serving as a global change agent. This is now possible because of the proliferation of these national voluntary programmes.

To what end is international collaboration needed? What needs to be changed that is essentially the same in South Africa as in the UK, in France as in Germany, in Japan as in Canada? For me one answer stands out: we all need to persuade health departments at every level to accept injury prevention, not only as a health issue, but as a leading health problem, requiring solid funding and strong interventions.

I realize not everyone will be comfortable with this push and some will accuse me of climbing on an old bandwagon. They will be correct. This is not a new idea: I have written and talked about it frequently. My reason for doing so yet again is simply that I believe it to be absolutely central to our collective mission. I hasten to add that in doing so I am in no way intending to relegate all the other major actors in injury prevention to secondary roles.

You may ask how there can be many leads in this drama? The answer to this rhetorical question is that just as any theatrical production has many lead actors, there is usually only one director. The director is ultimately responsible for the success of the production. The actors are pivotal, to be sure, but the script, how the words are spoken, when the actors enter and exit, are all determined by the director.
In the case of injury prevention, government departments of transport, justice, housing, or product safety, to cite but a few, each play a part, just as in research the disciplines of engineering, sociology, epidemiology, or psychology must contribute. But each has other priorities alongside injury prevention. Automotive engineers want to incorporate safety features, partly because they now realize that safety sells. But so does styling and cost, and left to their own devices, it is probable that impact resistant structures would not be a priority for automotive engineers. Now suppose, for a moment, the industry had no interest in safety features? Who would speak on behalf of passenger safety? As matters now stand, in most countries it would not be the health department.

To illustrate this point, table 2 lists 10 common preventable childhood injuries and the branch of government in Canada responsible for the implementation of the respective safety measures. ${ }^{1}$ Note that in only two instances does the health department enter the picture. Note also the large number of branches involved, and the fact that some responsibilities are federal, others provincial, and still others, municipal. I suspect this picture is similar in other countries. Accordingly, the need for leadership from health departments is evident.

At another level, international collaboration could lead to the sort of large scale randomized trial called for by Underwood and Carter in their Opinion column ( $p$ 6). Provided the caveats in Larson's Dissent are heeded ( $\mathrm{p} 8$ ), this may well prove feasible and widely beneficial. If the scientific community were to proceed in this direction, much careful attention should be given to the choice of topic and intervention. The prevention of injuries among preschoolers by fairly traditional, educational means, may not be everyone's cup of tea. It is not mine, but it remains to be seen if I am misguided.

Finally, to return to what is, perhaps, the key question: what should be done with this splendid opportunity to collaborate internationally? I have already suggested that at the top of my list would be a concerted effort to get health departments involved in, and committed to, injury prevention. Although each country would have to work separately, the task of the advocates would be easier if they could point to other countries that have taken this step and profited by it.

I B PLESS Editor

1 Building toward breakthroughs in injury control: a legislative perspective on the prevention of unintentional injuries among children and youth in Canada. Ottawa: Minister of Public Works and Government Services Canada, 1996. 